Brit. J. prev. soc. Med. (1959), 13, 1-4

\title{
THE SMOKING HABITS OF SCHOOL CHILDREN
}

\author{
BY
}

\author{
A STUDY GROUP OF THE PUBLIC HEALTH DEPARTMENT \\ London School of Hygiene and Tropical Medicine
}

In recent years there have been numerous reports about the relationship between smoking and carcinoma of the lung. The first published survey was carried out in Germany by Müller (1939). His findings have been confirmed by many other studies, including the extensive surveys of Wynder and Graham (1950) in the United States and Doll and Hill (1950) in England. The correlation between smoking, particularly cigarettes, and lung cancer is now widely accepted.

The continued increase in the incidence of bronchial carcinoma over the past few decades indicates that this condition is of major importance in public health to-day and may be of even greater importance in the future. Various attempts to warn, alarm, or merely to inform the public have had little or no obvious effect in changing the overall smoking habits of the population. To the group conducting the survey reported in this paper it seemed highly doubtful whether the approaches which have been tried are likely to prove effective. Since it is felt that smoking represents at least habituation, if not addiction, any effective programme for the control of lung cancer must be aimed at prevention of the habit of smoking until the specific carcinogens in tobacco can be identified and eliminated.

Several retrospective studies have been undertaken to ascertain the smoking habits of various groups, but those concerned with direct questioning of school children in Great Britain have been limited. The first (Jones, 1957) was based on a population of 307 boys in a secondary modern school. Of these, 38 per cent. had smoked before reaching the age of 11-12 years. Regular smoking rose sharply from 3 per cent. of the 11-year-olds to 44 per cent. of the 14-year-olds. Few smoked more than five cigarettes per week until the age of 13 to 14. Raven (1957) obtained his information from the head teachers of a variety of schools. Although many secondary modern school children had smoked their first cigarette before the age of 12 , regular smoking was not observed until the ages of 13-14. Early smoking was found to have a negative correlation with intelligence and was commoner in urban than in rural districts. In grammar schools and public schools as compared with secondary modern schools, smoking was less common, started at a later age and the number of cigarettes smoked was less at comparable ages. Taylor (1957) studied the smoking habits of boys in one grammar school and two secondary modern schools. In the former, 45 per cent. of the 14-16 age group smoked, 23 per cent. being regular smokers. In the latter, 62 per cent. of the 14-yearold boys smoked, 19 per cent. regularly.

All of these studies have demonstrated that the secondary school age is a critical period in the formation of smoking habits. The present report presents the results of a survey which, it is hoped, will serve as a basis for planning a more intensive search into the factors involved in the acquisition of the smoking habit by school children.

\section{METHOD}

Although questionnaires present several disadvantages for obtaining accurate information, it was decided that this method was the most practicable for a large survey in a group of schools. Construction of an appropriately simple questionnaire was accomplished with the aid and advice of Dr. Richard Doll. As a preliminary study the questionnaire was presented to three classes of secondary modern school boys approximately 3 months before the full scale study. It was found that only minor modifications were needed. Comparison with the answers given by the same pupils 3 months later served as a 
check both on memory and on the reliability of the method.

Questionnaires were completed in the classrooms. Instructions and questions were read to the pupils by their own teachers. To encourage truthful replies the confidential nature of the inquiry was stressed. In all but 25 out of 127 classes the completed forms were collected and placed in a sealed envelope by a member of the study group who was present to clarify any misunderstandings.

For the purpose of classifying smoking experience two arbitrary reference points were established:

(1) as little as one puff of a cigarette should be counted as "having smoked";

(2) the smoking of five or more cigarettes a week was defined as "regular" smoking.

Population STUdiED.-Through the co-operation of the Medical Officer of Health and the head teachers, it was possible to make a complete survey in two grammar schools and four secondary modern schools of an industrial County Borough near London. Tables I and II show the distribution of the children by age, sex, and type of school, and the percentages of children who completed the questionnaire satisfactorily.

No attempt was made to obtain information from those who were absent on the day of the survey. Questionnaires were rejected when the answers given were either insufficiently complete or confused, or if the child's age was not recorded. In all, 3,479 questionnaires representing 90 per cent. of the total school population and 98 per cent. of the children available for investigation were included in the analysis.
TABLE II

QUESTIONNAIRES USED FOR ANALYSIS, BY SEX, AGE, AND TYPE OF SCHOOL

\begin{tabular}{|c|c|c|c|c|c|}
\hline \multirow{2}{*}{$\frac{\text { Sex .. }}{\text { School }}$} & \multirow{2}{*}{ 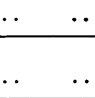 } & \multicolumn{2}{|c|}{ Boys } & \multicolumn{2}{|c|}{ Girls } \\
\hline & & Grammar & $\begin{array}{l}\text { Secondary } \\
\text { Modern }\end{array}$ & Grammar & $\begin{array}{l}\text { Secondary } \\
\text { Modern }\end{array}$ \\
\hline \multirow[t]{2}{*}{$\begin{array}{l}\text { Age } \\
\text { (yrs) }\end{array}$} & $\begin{array}{l}11- \\
12- \\
13- \\
14- \\
15- \\
16- \\
17+\end{array}$ & $\begin{array}{r}67 \\
136 \\
159 \\
151 \\
110 \\
67 \\
70\end{array}$ & $\begin{array}{r}187 \\
246 \\
277 \\
243 \\
65 \\
19 \\
-\end{array}$ & $\begin{array}{r}66 \\
96 \\
111 \\
115 \\
106 \\
54 \\
54\end{array}$ & $\begin{array}{r}175 \\
242 \\
285 \\
276 \\
80 \\
22 \\
-\end{array}$ \\
\hline & Total & 760 & 1,037 & 602 & 1,080 \\
\hline \multicolumn{2}{|c|}{ Total by Sex } & \multicolumn{2}{|c|}{1,797} & \multicolumn{2}{|c|}{1,682} \\
\hline \multicolumn{2}{|c|}{ Grand Total } & \multicolumn{4}{|c|}{3,479} \\
\hline
\end{tabular}

The population is fairly evenly distributed throughout the age groups. The paucity of 11-yearold grammar school children can probably be explained by differences in selection for entry to these schools. The smaller 15- and 16-year-old groups in secondary modern schools are due to the earlier leaving age in this type of school.

\section{RESULTS}

As might have been expected, the overall results show first that the degree of smoking experience is related to the age of the group and secondly that the figures for boys are consistently higher than those for girls of the same age (Table III, opposite). In addition, it is apparent that the percentages are higher among secondary modern school children than among grammar school children of the same age, but these differences are less striking among the girls than among the boys.

TABLE I

NUMBER OF SCHOOL CHILDREN INCLUDED IN SURVEY

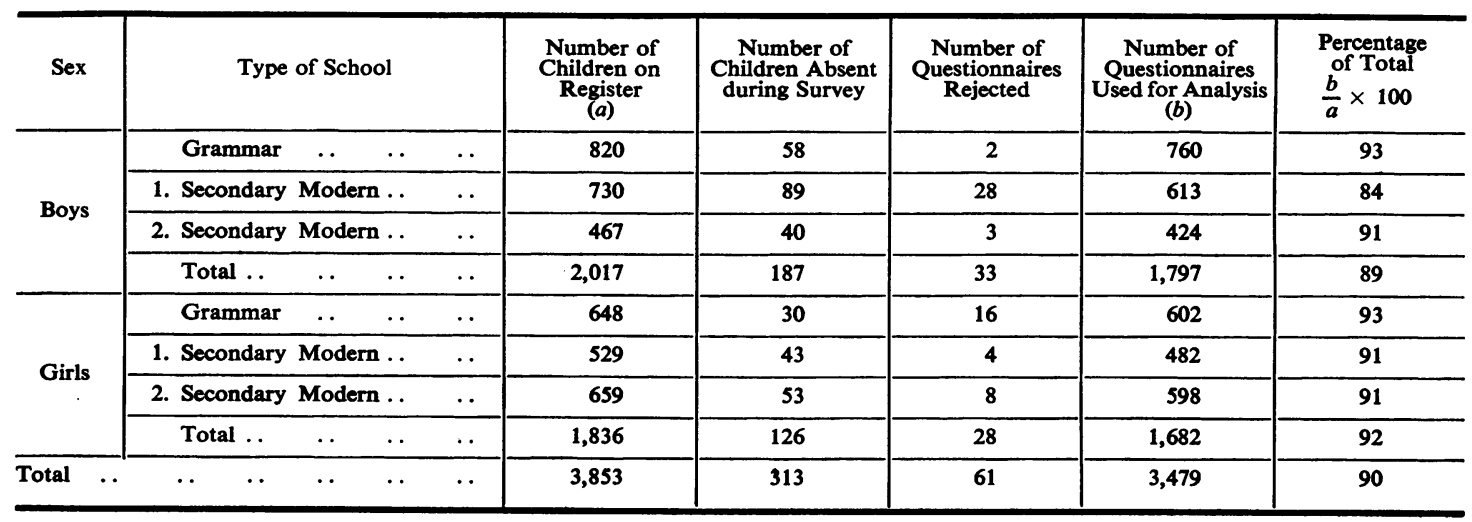


TABLE III

PERCENTAGE OF CHILDREN WHO HAD SMOKED, BY SEX, AGE, AND TYPE OF SCHOOL

\begin{tabular}{|c|c|c|c|c|c|}
\hline \multirow{2}{*}{$\frac{\text { Sex } \ldots}{\text { School }}$} & \multirow{2}{*}{$\begin{array}{ll}\cdots & \cdots \\
\cdots & \cdots\end{array}$} & \multicolumn{2}{|c|}{ Boys } & \multicolumn{2}{|c|}{ Girls } \\
\hline & & Grammar & $\begin{array}{c}\text { Secondary } \\
\text { Modern }\end{array}$ & Grammar & $\begin{array}{l}\text { Secondary } \\
\text { Modern }\end{array}$ \\
\hline $\begin{array}{l}\text { Age } \\
\text { (yrs) }\end{array}$ & $\begin{array}{l}11- \\
12- \\
13- \\
14- \\
15- \\
16- \\
17-\end{array}$ & $\begin{array}{l}40 \cdot 3 \\
47 \cdot 8 \\
58 \cdot 5 \\
66 \cdot 2 \\
74 \cdot 5 \\
80 \cdot 6 \\
72 \cdot 9\end{array}$ & $\begin{array}{l}71 \cdot 1 \\
81 \cdot 7 \\
84 \cdot 9 \\
89 \cdot 3 \\
86 \cdot 2 \\
89.5 \\
-\end{array}$ & $\begin{array}{l}21 \cdot 2 \\
40 \cdot 6 \\
45 \cdot 0 \\
53 \cdot 9 \\
63 \cdot 2 \\
61 \cdot 1 \\
75 \cdot 9\end{array}$ & $\begin{array}{c}38 \cdot 0 \\
43 \cdot 4 \\
56 \cdot 1 \\
59 \cdot 8 \\
61 \cdot 3 \\
36 \cdot 4 \\
-\end{array}$ \\
\hline
\end{tabular}

According to our definition, 8 per cent. of all the children in the survey qualified as "regular" smokers. Analysis, on the basis of age, sex, and type of school, revealed trends similar to those for general smoking experience (Table IV). The levelling off in the boys and the irregularity in the figures for girls over 15 years of age may be due to sampling errors arising from the smallness of the groups or to a process of selection among those who had passed the schoolleaving age.

TABLE IV

PERCENTAGE OF REGULAR SMOKERS*, BY SEX, AGE, AND TYPE OF SCHOOL

\begin{tabular}{|c|c|c|c|c|c|c|}
\hline \multirow{2}{*}{$\begin{array}{l}\text { Sex... } \\
\text { School }\end{array}$} & \multirow{2}{*}{$\cdots$} & \multirow{2}{*}{$\cdots$} & \multicolumn{2}{|c|}{ Boys } & \multicolumn{2}{|c|}{ Girls } \\
\hline & & & Grammar & $\begin{array}{c}\text { Secondary } \\
\text { Modern }\end{array}$ & Grammar & $\begin{array}{l}\text { Secondary } \\
\text { Modern }\end{array}$ \\
\hline $\begin{array}{l}\text { Age } \\
\text { (yrs) }\end{array}$ & & & $\begin{array}{l}0 \\
0 \\
1 \cdot 9 \\
15 \cdot 9 \\
25 \cdot 5 \\
23 \cdot 9 \\
27 \cdot 1\end{array}$ & $\begin{array}{r}3.2 \\
9.8 \\
21.3 \\
29.6 \\
35.4 \\
31.6 \\
-\end{array}$ & $\begin{array}{l}0 \\
0 \\
1 \cdot 8 \\
5 \cdot 2 \\
4 \cdot 7 \\
3 \cdot 7 \\
3 \cdot 7\end{array}$ & $\begin{array}{l}0 \\
0 \cdot 4 \\
2 \cdot 8 \\
3 \cdot 6 \\
5 \cdot 0 \\
0 \\
-\end{array}$ \\
\hline
\end{tabular}

i.e. five or more cigarettes/week*

Table V shows the smoking habits of the 260 boys aged 11-16 years who were regular smokers. One third of those aged 14-16 were smoking more than twenty cigarettes a week.

TABLE V

HABITS OF REGULAR SMOKERS AGED 11-16

\begin{tabular}{|c|c|c|c|c|c|}
\hline \multirow{2}{*}{$\underset{\text { (yrs) }}{\text { Age }}$} & \multicolumn{4}{|c|}{$\begin{array}{c}\text { Percent Smoking } \\
\text { (Cigarettes per Week) }\end{array}$} & \multirow{2}{*}{$\begin{array}{c}\text { No. } \\
\text { in } \\
\text { Group }\end{array}$} \\
\hline & $5-9$ & $10-19$ & $20-39$ & 40 or more & \\
\hline $11-13$ & 46 & 34 & 13 & 7 & 92 \\
\hline $14-16$ & 36 & 31 & 21 & 12 & 168 \\
\hline
\end{tabular}

The distribution of the intervals between the first smoking experience and the onset of regular smoking among the group of regular smokers is shown in Table VI. The majority of these acquired the habit within one year of their first cigarette and nearly 95 per cent. within 3 years. The numbers in various age groups were not sufficiently large to evaluate the influences of age with respect to the rapidity of development of the habit.

TABLE VI

INTERVAL BETWEEN FIRST SMOKING EXPERIENCE AND ONSET OF REGULAR SMOKING AMONG BOYS AGED 11-16

\begin{tabular}{c|c|c}
\hline $\begin{array}{c}\text { Interval } \\
\text { (yrs) }\end{array}$ & $\begin{array}{c}\text { Number of } \\
\text { Regular Smokers }\end{array}$ & $\begin{array}{c}\text { Percentage } \\
\text { of Total }\end{array}$ \\
\hline $0-$ & 159 & 61 \\
$1-$ & 59 & 23 \\
$2-$ & 28 & 11 \\
$3-$ & 3 & 1 \\
$4-$ & 5 & 2 \\
$5-$ & 260 & 100 \\
\hline Total & 5 & 2 \\
\hline
\end{tabular}

Table VII shows the percentages of secondary modern school boys who had smoked, according to age group and intelligence. The difference is not statistically significant but over the age of 12 the proportion of boys who had smoked was consistently higher in the lower stream.

TABLE VII

RELATIONSHIP BETWEEN INTELLIGENCE AND SMOKING AMONG SECONDARY MODERN SCHOOLBOYS

\begin{tabular}{c|c|c|c|c|c|c}
\hline \multirow{2}{*}{ Stream } & \multicolumn{5}{|c|}{ Percentage who had Smoked in Each Age Group } \\
\cline { 2 - 7 } & $11-$ & $12-$ & $13-$ & $14-$ & $15-$ & All Ages \\
\hline Upper & $72 \cdot 4$ & $77 \cdot 2$ & $82 \cdot 4$ & $87 \cdot 4$ & $85 \cdot 7$ & $81 \cdot 2$ \\
\hline Lower & $69 \cdot 9$ & $89 \cdot 2$ & $86 \cdot 3$ & $92 \cdot 4$ & $93 \cdot 3$ & $84 \cdot 7$ \\
\hline
\end{tabular}

(For all ages $P>0 \cdot 1$ )

\section{Discussion}

In a study of this type, one may always question the validity of the answers given. Every effort was made to stress the confidential nature of the inquiry in order to obtain answers which were as truthful as memory would permit. On the basis of comparison of answers given 3 months apart by a group of 81 secondary modern school boys aged $11-15$, it was felt that the answers given were relatively reliable. 68 who had stated that they had smoked at the time of the first questionnaire gave the same answer the second time. One who had answered "No" on the first occasion converted to "Yes". The answers concerning the age at which they had first smoked showed some variation, though this was not great: 47 per cent. gave the same age on both occasions, 39 per cent. showed a variation of plus or minus one year, and $12 \cdot 5$ per cent. showed a variation of plus or minus 2 years.

It is difficult to compare the specific results of this survey with those obtained by other workers in 
other areas of Great Britain because the methods of questioning and classification differ. In general, however, this study confirms the findings of others in indicating that smoking is a relatively common practice among children of secondary school age, that there are definite age and sex differences, and that certain environmental factors may play a significant role in influencing the patterns of smoking experience.

For both boys and girls there is a consistent increase with age in the percentage of the group who have smoked at some time in their lives. Figures for boys are invariably higher than those for girls of the same age and those for secondary modern school children are consistently higher than those for the same age groups in grammar schools. This latter difference, however, is far less striking among girls than among boys.

The differences noted between the smoking patterns of secondary modern school as compared with grammar school children suggests a possible inverse relationship with intelligence. Though intelligence may be an important factor in this instance, such a relationship is less evident when one compares the upper stream and lower stream boys within the secondary modern schools. It is possible, therefore, that the school environment may play as great a role as intelligence in the development of smoking patterns. However, detailed conclusions cannot be drawn from these results.

Perhaps the most impressive findings were the high percentage of 11-year-old children who had already smoked, the percentage over the age of 13 who were regular smokers, and the relative rapidity with which the regular smokers developed the habit.

The overall results and impressions gained from this survey suggest that the secondary school age group should offer fertile ground for a school health education programme concerned with smoking. The specific roles of the various environmental and psychological factors involved require much more detailed studies. It is hoped that these further explorations may be carried out in the near future since the structure of an effective health education programme would depend to a large extent on the findings of such a study.

\section{SUMmaRY}

Nearly 3,500 boys and girls aged 10 to 18 years, representing 90 per cent. of the pupils at four secondary modern and two grammar schools in an industrial County Borough, were questioned about their cigarette smoking experiences. The smoking habits of these children have been related to age, sex, type of school, and intelligence.

The results indicate that smoking is a problem of significant importance among school children in an area such as the one surveyed. Smoking is commoner among boys than among girls and also commoner in secondary modern than in grammar school children. It is possible that the cultural pattern of the school may be as important as intelligence in influencing smoking behaviour. Among those boys who had become regular smokers, over 80 per cent. did so within 2 years of smoking their first cigarette.

It is suggested that there is an urgent need for health education in schools to abate smoking. This should be based on the results of further surveys aimed at determining those factors which may be important in influencing children to smoke.

We wish to thank Dr. J. S. Coleman, Medical Officer of Health, who enabled us to carry out this study; the headteachers and staff of the schools for their co-operation; Dr. Richard Doll for his advice in planning the questionnaire; and Miss V. Follenfant and Miss J. Cooper for their assistance at various stages of this investigation.

The study group consisted of the following:

S. P. W. Chave and R. S. F. Schilling, Staff Members of the London School of Hygiene and Tropical Medicine.

D.P.H. students of this School:
E. J. Coulter
W. R. Davies
R. Neumann
R. W. McCollum
J. H. Sewart
W. H. McDonald
L. S. Sodhy
G. S. Udall

(Chairman)

(Secretary)

W. R. McKibben

Senior students from the Royal College of Nursing:
R. A. Davis
E. D. Shaw
A. Pope
J. L. Wanigasuriya

The first draft of this report was prepared by $R$. W. McCollum. Inquiries about this study should be addressed to S. P. W. Chave.

\section{REFERENCES}

Doll, R., and Hill, A. Bradford (1950). Brit. med. J., 2, 739.

Jones, A. Parry (1957). Lancet, 1, 631.

Müller, F. H. (1939). Z. Krebsforsch., 49, 57.

Raven, R. W. (1957). Lancet, 1, 1139.

Taylor, G. R. (1957). Personal Communication.

Wynder, E. L., and Graham, E. A. (1950). J. Amer. med. Ass., 143, 329. 